\title{
Belgeo
}

Revue belge de géographie

\section{Allegorical images of Europe in some atlas titlepages, frontispieces, and map cartouches}

Les figures allégoriques de l'Europe dans quelques pages titres d'atlas, frontispices et cartouches

\section{Rodney Shirley}

\section{(2) OpenEdition}

\section{Journals}

Electronic version

URL: http://journals.openedition.org/belgeo/8811

DOI: 10.4000/belgeo.8811

ISSN: 2294-9135

Publisher:

National Committee of Geography of Belgium, Société Royale Belge de Géographie

Printed version

Date of publication: 31 December 2008

Number of pages: 341-354

ISSN: 1377-2368

\section{Electronic reference}

Rodney Shirley, "Allegorical images of Europe in some atlas titlepages, frontispieces, and map cartouches", Belgeo [Online], 3-4 | 2008, Online since 22 May 2013, connection on 05 February 2021. URL: http://journals.openedition.org/belgeo/8811 ; DOI: https://doi.org/10.4000/belgeo.8811

This text was automatically generated on 5 February 2021

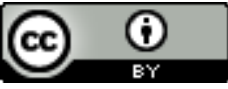

Belgeo est mis à disposition selon les termes de la licence Creative Commons Attribution 4.0 International. 


\section{Allegorical images of Europe in some atlas titlepages, frontispieces, and map cartouches}

Les figures allégoriques de l'Europe dans quelques pages titres d'atlas, frontispices et cartouches

Rodney Shirley

1 Since the $16^{\text {th }}$ century many atlases of maps and, more widely, works of geography, cosmography, exploration and travel have been preceded by highly decorative titlepages and/or frontispieces presenting their contents in symbolic form. Their aim is to attract the potential reader, first opening the book, by a visual expression of the contents of the work that is to follow. Similar visual messages may be imparted through the decorative cartouches of maps. Typically, from the 1570s and over the next 300 years these printed engravings employ the language of allegory, fable, imagery and classical references to achieve this end. The image of Europe (or Europa) is only one of very many such visual representations.

One of the earliest classical tales that influenced Renaissance scholars was the fable of the abduction of Europe derived from Ovid's famed Metamorphoses, written in about AD 7 when Ovid was in his late forties and at the height of his poetic vigour. This tale is found at the end of book II, lines $836-875$, although Ovid is known to have tapped into much earlier Graeco-Roman mythology going back several centuries BC. In brief, the maiden Europa, a Phoenician by lineage, was gathering flowers on the sea-shore with her female attendants. From afar off in the heavens the god Jupiter (or Jove or Zeus) espied Europa and became enamoured of her. Transforming himself into a handsome white bull he came close to the shore, enticed her onto his back and seductively allayed her fears so that she wound a chain of flowers around his horns. As he swam out to sea she naively waves a farewell to her companions. Details vary in other accounts-in some she is astride his back ; in others she sits gracefully side-saddle. Sources differ as to where Jupiter took his bride. Some say to Crete as its first queen ; others suggest that 
she was carried across the seas to the more distant land that would later bear her name.

However, the image of Europe that appears in the well-known titlepage to Abraham Ortelius' Theatrum Orbis Terrarum of 1570, the first standardised world atlas of its time, is not taken from Ovid. Shown as Figure 1, it has within an architectural structure, images of five women representing the known continents of the time ${ }^{1}$. Four figures show Africa, Asia, America and the supposed and only partly known land Magellanica. At the top of the architectural ensemble is the figure of Europe (Figure 1a). She sits on a throne as if superior to all other peoples of the world and, as well as being crowned, holds a sceptre in her right hand and in her left grasps a cross secured to a large orb of the earth. The cross signifies her Christian Catholic religion and, to add further emphasis, she is seated under a pergola decked with vine shoots and clusters of grapes. These were emblematic of Christ's blood, as drunk as part of the Christian Eucharist.

Within the atlas itself, the map of the continent of Europe has a small mythological image which is part of the title in the upper left part of the map. This map would seem to be the first to make use in a limited way of the image of a bull bearing a maiden on his back. Both figures are placed on a plinth containing the title of the map, Europe.

Figure 1. Titlepage to the atlas Theatrum Orbis Terrarum of Abraham Ortelius, Antwerp, 1570. The example shown is from a later German-text titlepage, dating from 1572.

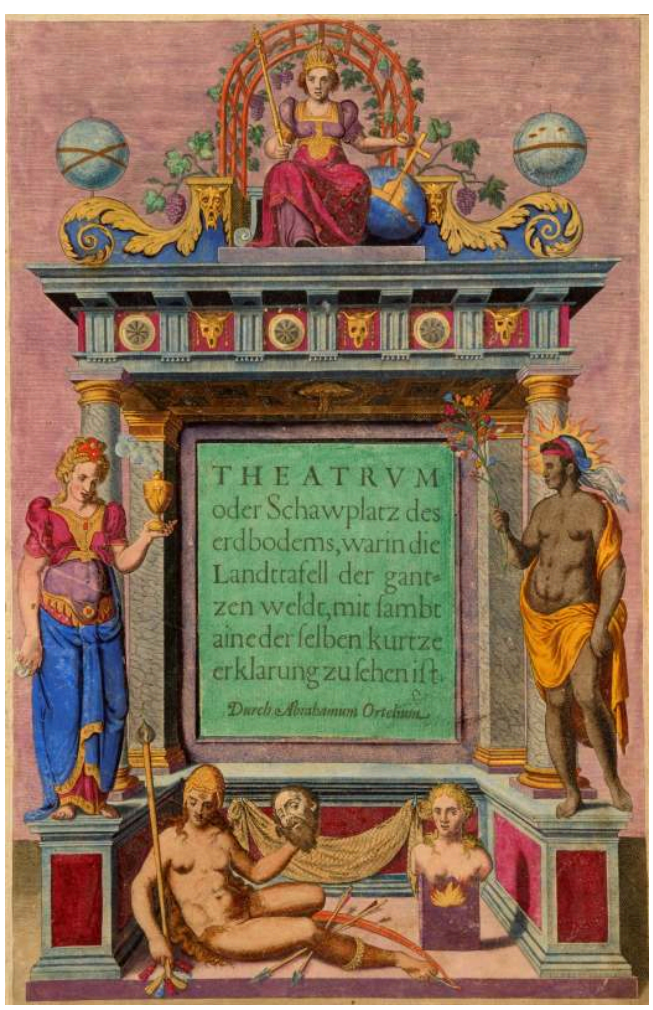


Figure 1a. Detail, showing figure of Europe enthroned.

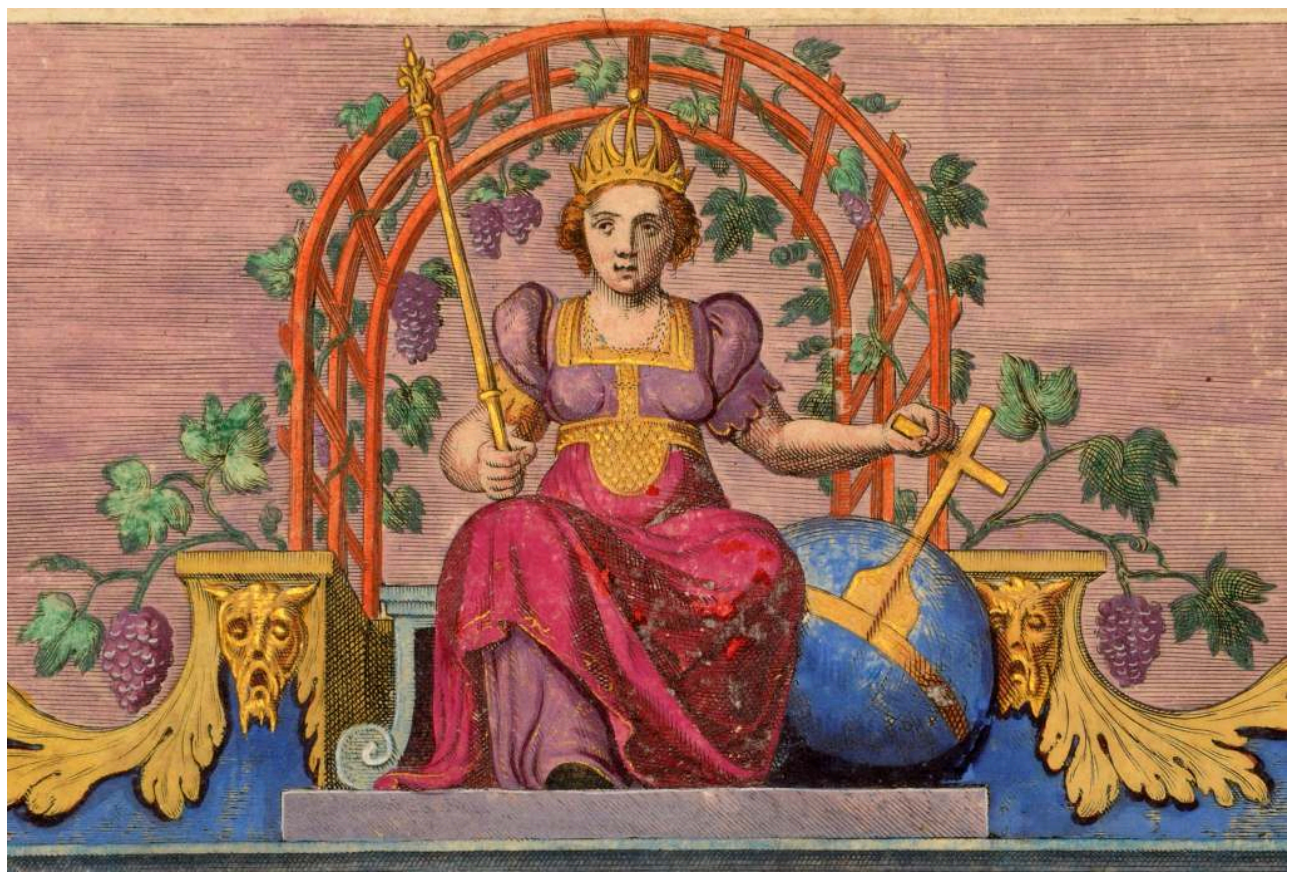

Ortelius' atlas had a wide circulation, with text in seven different languages and more than 30 editions from 1570 until 1612. However, as far as is known, there were no direct derivatives of the striking frontispiece over this time and the rival atlas-makers of Mercator and (later) Hondius and his successors did not incorporate a similar figure of Europe in their titlepages or maps although images of the other continents were often depicted. There was a unique compilation of maps by Gerard Mercator in 1570-72 known as the Atlas Europae but without either titlepage or frontispiece. Mercator's own wall map Europae Tabula was provided with a traditional Mannerist cartouche embracing the title and a similar cartouche was used by his son Rumold for his smaller two-sheet map of Europe printed in 1595.

6 An atlas contemporary with those published by Ortelius is the Europae Totius Orbis Terrarum of Matthias Quad, published by the Cologne firm of Johann Bussemacher in $1592^{2}$. It contains 50 maps of the countries and local states of Europe, and the image of Europa and her abducting bull is seen as a small vignette at the foot of the titlepage (Figure 2). There is no textual explanation of its significance, suggesting that the meaning of the bull symbol signifying the rape of Europa would be sufficiently understood by the likely purchasers and readers of Quad's atlas. At the top is a doubleheaded eagle associated with the Hapsburg rule: probably more reflective of the allegiance of Cologne within the Holy Roman Empire than any reflection of Europe as a whole. 
Figure 2. Titlepage to the atlas Europae Totius Orbis Terrarum of Matthaus Quad, Cologne, 1592.

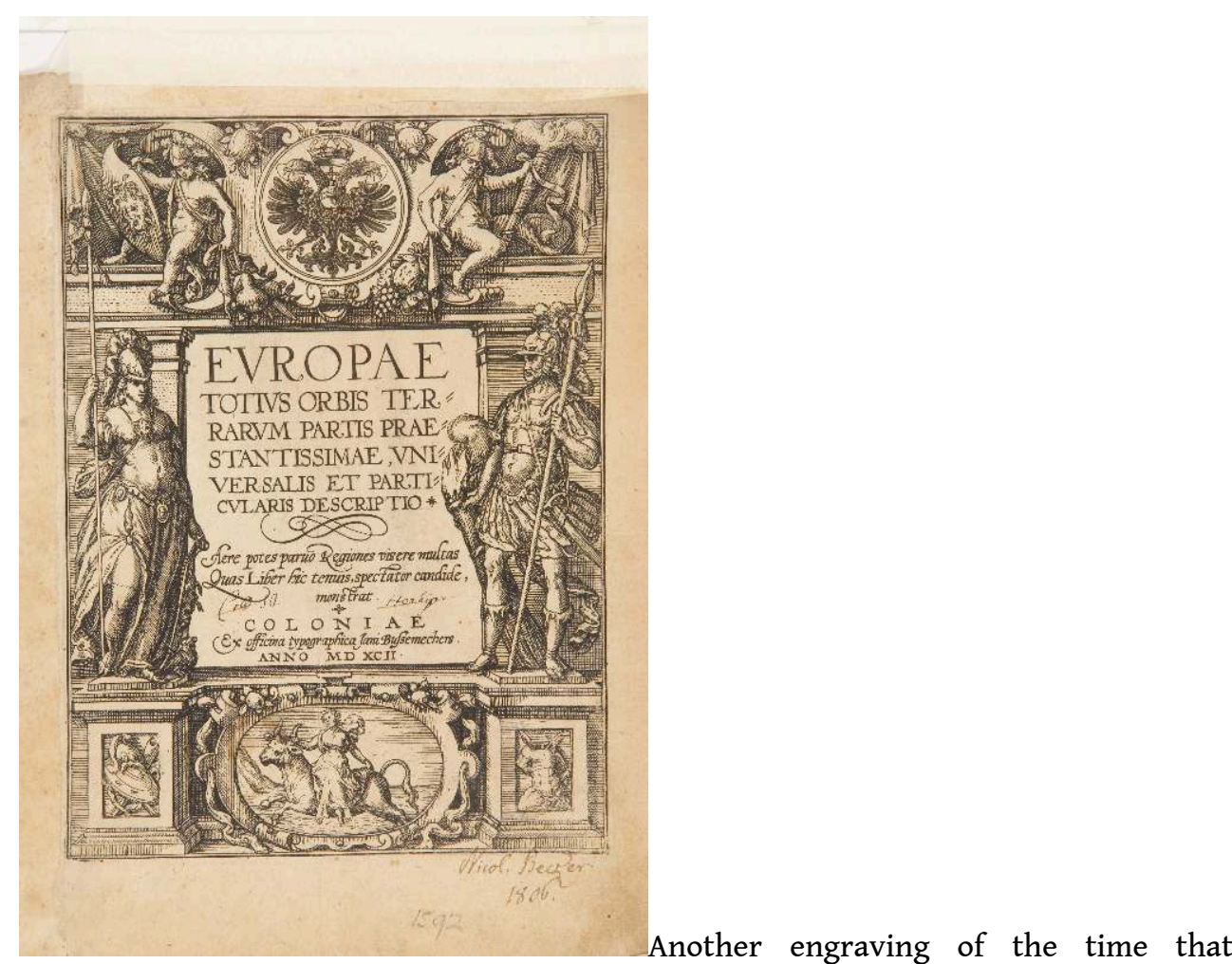
features the figure of Europe is the atlas titlepage to the Magini edition of the Geographia of Claudius Ptolemaeus, more commonly known as Ptolemy. It was published from Cologne by Peter Keschedt in 1597 and later by Jan Janszoon from Arnhem in 1617. The figure Europa reclines in the top left part of an oval configuration, with the other continents being depicted in the remaining corners. Europe holds her sceptre but, unusually, is accompanied by a bear as her animal attribute. In most other instances her animal attribute is a horse. The monogram initials C v P at the foot are those of the engraver Crispin van Passe.

7 It is not until the mid- $17^{\text {th }}$ century that, through the medium of Joan Blaeu's multivolume Atlas Maior (or Grand Atlas) of 1662, a more splendid picture of the abduction of Europa appears ; in this instance as the frontispiece of the Europe section of the Atlas Maior (Figure 3). The frontispiece is unsigned but is not unreasonably attributed to Joannes de Visscher by comparison with his other (signed) works. The source for Blaeu's atlas may have been the 1562 painting by Titian although Titian was not alone in reading Ovid's Metamorphoses and in taking Jupiter's bold adventure as his theme. The engraving is an elegant one, showing Europa sitting easily on the back of a determined Jupiter (disguised as a bull), and grasping one of his horns. Europa, with her red cloak swirling behind her, seems to show pleasureable anticipation rather than the fear and distress exhibited by her companions left on shore ${ }^{3}$. 
Figure 3. Frontispiece to the European section of the Atlas Maior of Joan Blaeu, Amsterdam, 1662.

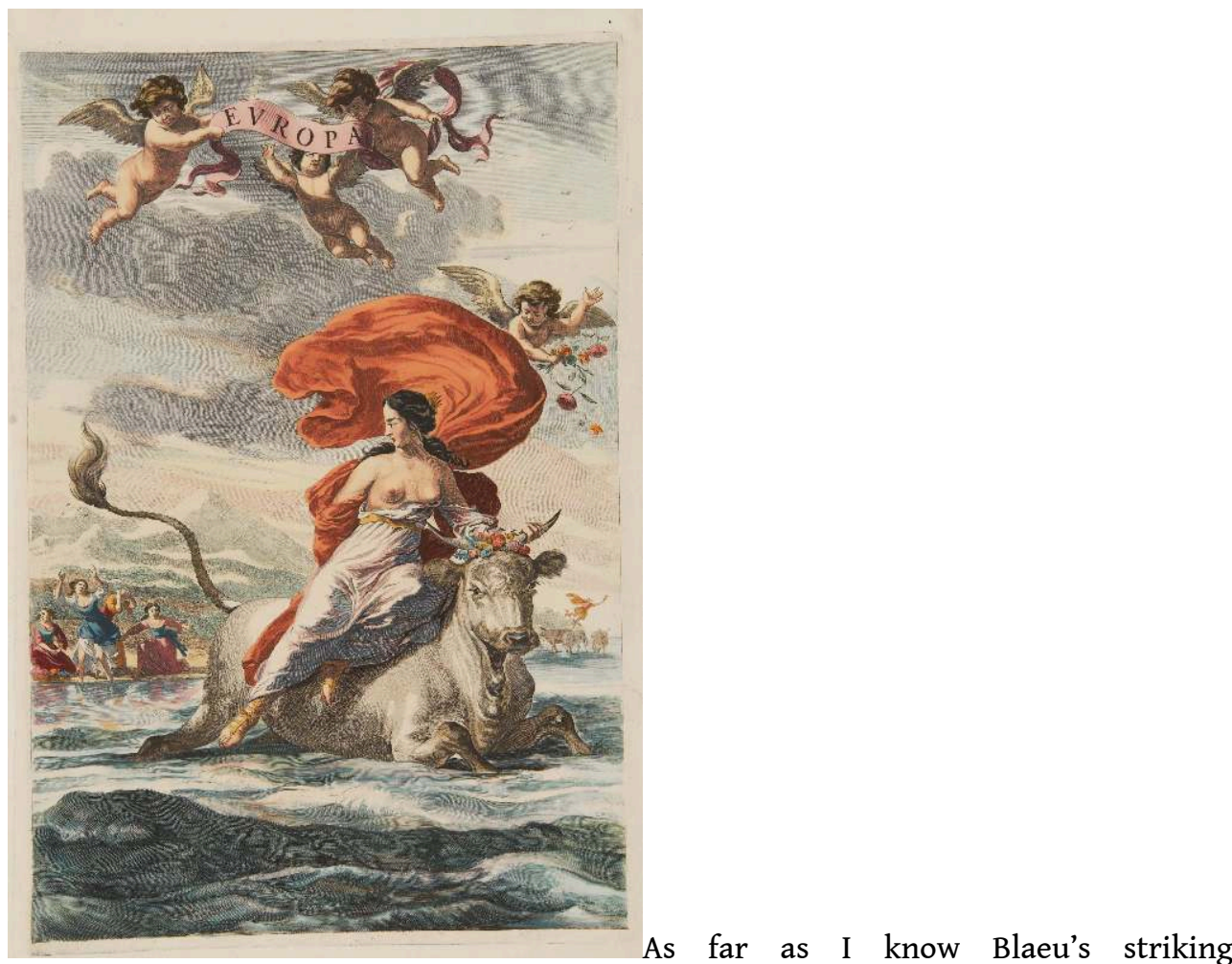

frontispiece was not copied by other atlas-makers. However, some 35 years later the same theme appears as the frontispiece to a historical work Histoire de l'Angleterre, d'Ecosse et d'Irlande by Isaac de Larrey, first published by Reinier Leers from Rotterdam in 1697 (Figure 4). Europa here appears as a more frantic captive, while her shore companions under a large portico headed Magna Britannia look on in stony-hearted disregard. The political significance of this scene (if any) is not immediately apparent. 
Figure 4. Frontispiece to the Histoire d'Angleterre, d'Ecosse et d'Irlande by I. de Larrey, Rotterdam, 1697. Example shown is a later edition by Covens \& Mortier, Amsterdam, c.1730.

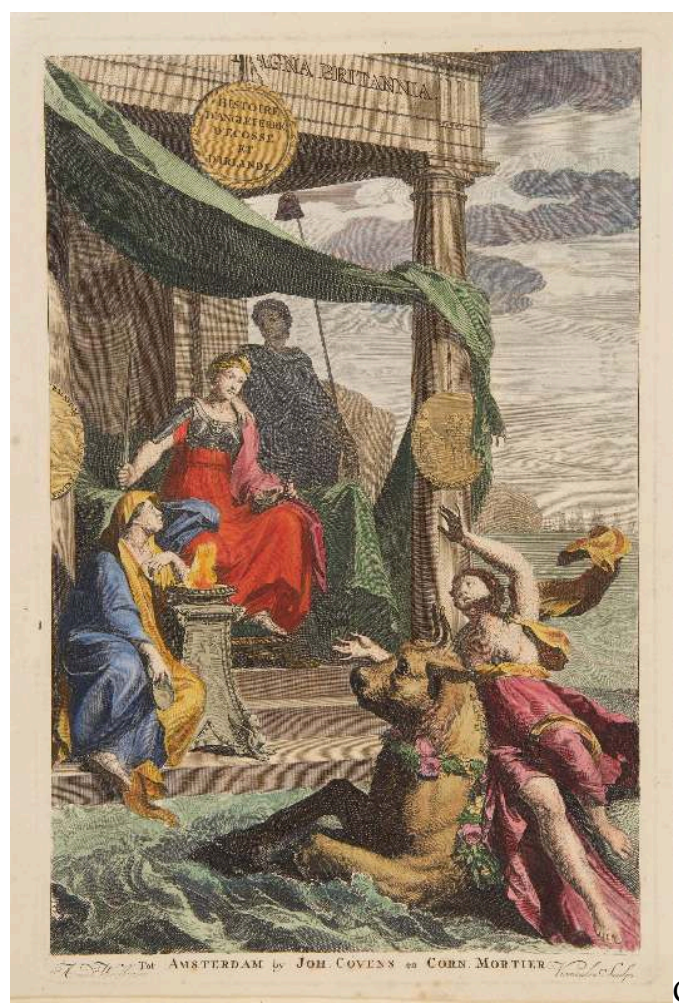

Other map-makers in the seventeenth and early eighteenth centuries who included the image of Europa and her abducting bull within their European map cartouches were Pieter van den Keere (Petrus Kaerius), 1614 ; Hugo Allard, c.1650 ; Frederick de Wit and Justus Danckerts, both the latter in the 1680 s and 1690 s.

8 Not all allegorical images of Europe presented the coupling of Europa and Jupiter as a bull. A map of Europe by Jodocus Hondius dated 1602, later published by Jean Le Clerc, shows the figure of Europe flanked by various scientific instruments. A different picture of Europe is to be found in the titlepage to Sir Thomas Herbert's 1638 work Travels into Persia and Industani [and] other Kingdoms in the Orientall Indies (Figure 5). As part of the top vignette, Europe is seated on a straight-backed chair and is being assaulted by two fierce-looking Turks with drawn swords. She is using her tall cross and sceptre to try and keep them at bay. This miniature piece reflects the warring excursions between Christians and Ottomans that were common throughout the 17th century. These encounters reached a climax in 1683 when Ottoman forces were hammering at the fortifications of Vienna and were only just repulsed from sweeping further over central Europe. 
Figure 5. Detail from the titlepage to the Travels... Into Persia and Industani... by Sir Thomas Herbert, London, 1638.

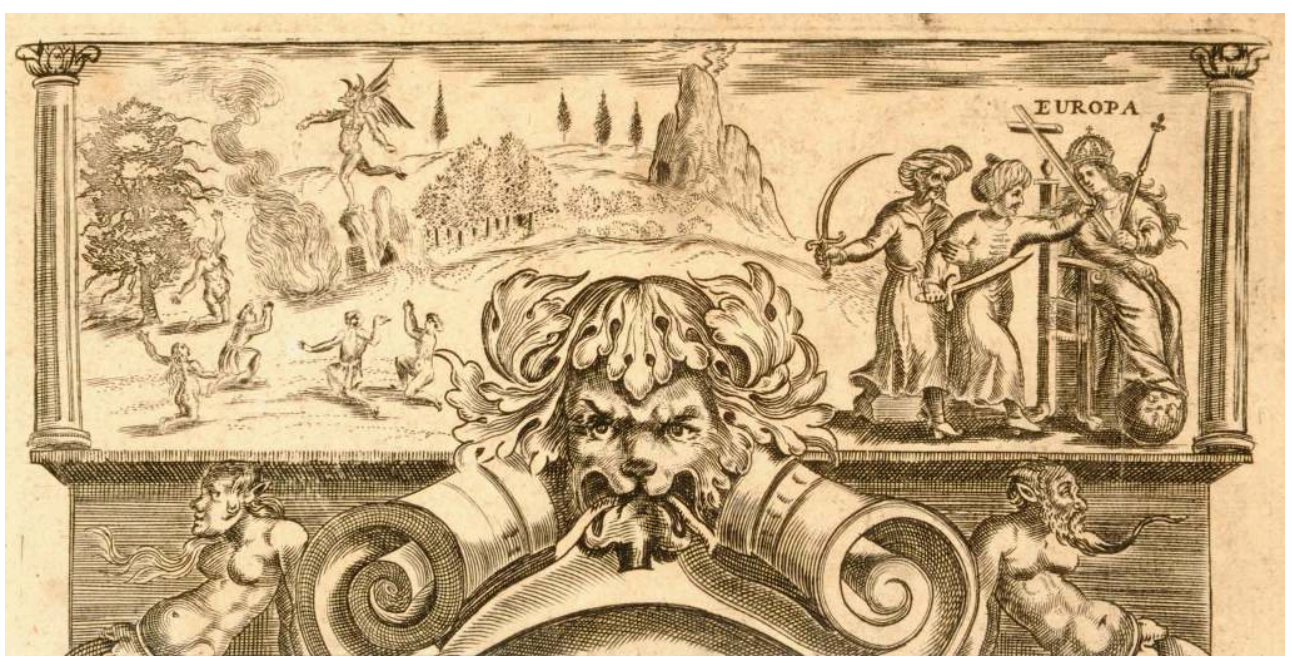

Also worthy of mention is the wounded male figure in the centre of the 1682 titlepage to Part XI of Matthäus Merian's multi-volume work Theatrum Europaeum (Figure 6). The figure represents the battered persona of Europe at the end of the Thirty Years War that devastated central Europe in the mid-seventeenth century. Crowned with a laurel wreath, he is comforted by the two female figures: the one on the left captioned as Honour and on the right Bellona, the Roman goddess of war - the wife (or sister) of Mars - who is offering an olive branch of peace ${ }^{4}$.

Figure 6. Frontispiece to the Theatrum Europaeum by Matthäus Merian, Part XI, Frankfurt-amMayn, 1682.

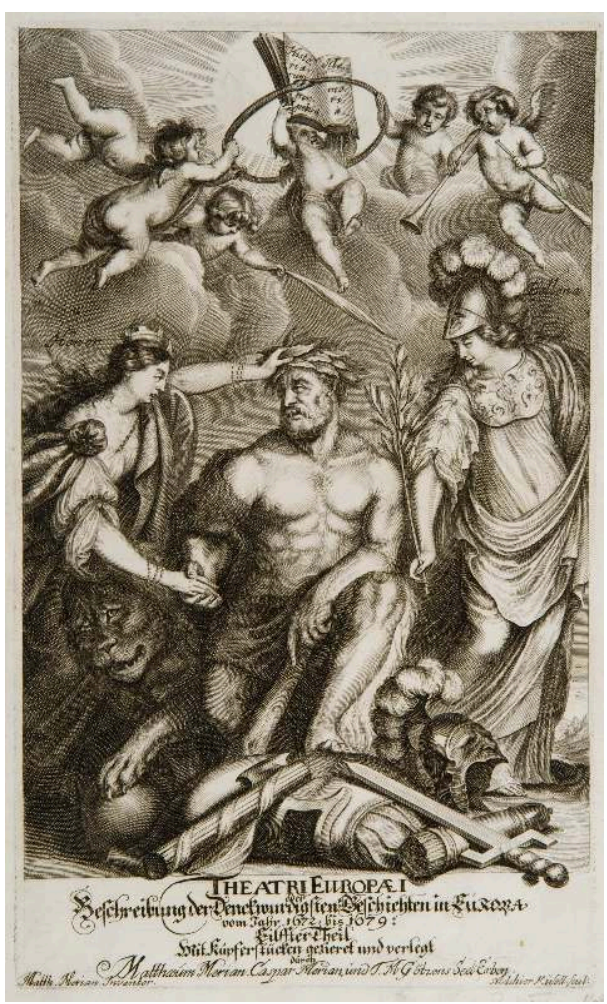


An even more elaborate image is to be found in the large decorative cartouche to the map of Europe by Pieter (or Pierre) van der Aa, from his Le Nouveau Theatre du Monde published in 1713 or 1714 (Figure 7). The seated figure of Europe is personified as that of Cybele with her turreted crown, the earth-mother goddess of cities. She grasps a miniature circular Christian temple, the embodiment of her faith. On the right is a vine with clusters of grapes and on the left a further cornucopia signifying bountiful harvests. Europa points to a golden tiara and other sceptres and crowns - emblems of authority - at her feet. Beneath her throne is a large decorated vase flanked by two putti who point to a picture painted or sculpted on it, of the fable of Europa being carried away by Jupiter disguised as a bull.

Figure 7. Cartouche from the map of Europe by Pieter van de Aa, from his Le Nouveau Théâtre du Monde, c.1713.

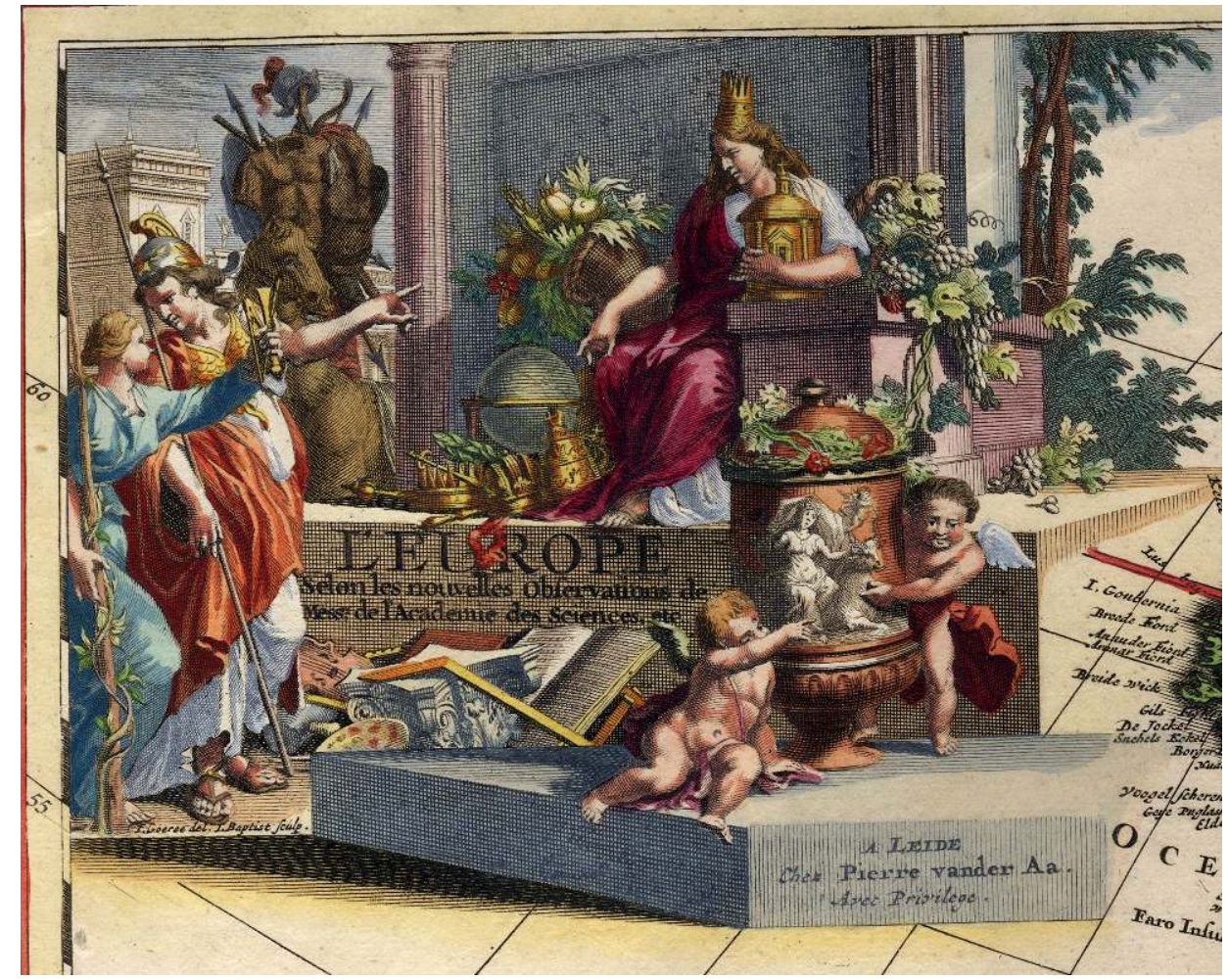

11 Further to the left are two figures : the taller is Minerva or Pallas Athene, the helmeted goddess of war but also patroness of learning and the arts. She stands in front of a cluster of accoutrements of a military nature, including the figure of a horse - long accepted as the principal animal attribute of the continent of Europe. The figure on the very left, who Minerva is addressing while pointing to Europa, probably represents the Arts and the Sciences for which Europe is famed. She holds several geometric instruments in her left hand while in front of her, in the foreground, are symbols of music (a violin), painting (a palette), architecture (a Corinthian capital), a book (literature) and drawing (a T-square). The plant climbing up the long staff resting on her right hand may be a reminder of the science and art of horticulture.

The whole ensemble is intended to glorify both the power and the culture that is inherent in the assembly of nations forming the continent of Europe. Threats from the Ottoman East have been relegated to the past. Van der Aa's piece is a skilfully balanced composition, signed by Jan Goeree as designer and J. Baptist as engraver. Jan Goeree 
engraved several maps for Jaillot as well as for Van der Aa ; the second-named artist is less well known.

The cartouche to the map of Europe by the English map-maker John Senex dating from 1721 includes an unusual additional allegorical image. Here the figure of Europe holds a small statuette of Nike, the Greek goddess of victory with her palm tree branch. At the feet of Europe are four putti with instruments of scientific measurement and surveying imparting the message of a sophisticated continent victorious over, or superior to, other lands in war and the sciences. The Germanic European maps by J. B. Homann (1706) and later by T. C. Lotter (c.1750) place more emphasis on (Christian) religious symbolism as a decorative backdrop to the figures of Europe gracing their title cartouches.

Towards the end of the eighteenth century the Italian painter and map-maker Giovanni Maria Cassini produced a world atlas in three volumes titled the Nuovo Atlante $e^{5}$. As far as is known the author is not directly related to the distinguished Cassini family who mapped France throughout the $18^{\text {th }}$ century. Figure 8 shows the titlepage to volume I of Cassini's Nuovo Atlante (1792) with the crowned figure of Europe sitting on a large stone base. Behind her is a large mounted globe, somewhat unusually oriented so that west is at the top. To the right is a horse, the animal-attribute of Europe, and in front of her is a cornucopia of flowers and further objects representing the sciences and the arts. The female personification of Asia is to her right ; the further continental figures of Africa and America are in the background also with their animal attributes. Compositions with similar imagery form the titlepages to volumes II and III. According to visible signatures the volume I titlepage was designed by Stefano Tosanelli and engraved by Alessandro Mochetti.

Figure 8. Titlepage to the Nuovo Atlante of Giovanni Maria Cassini, 1792.

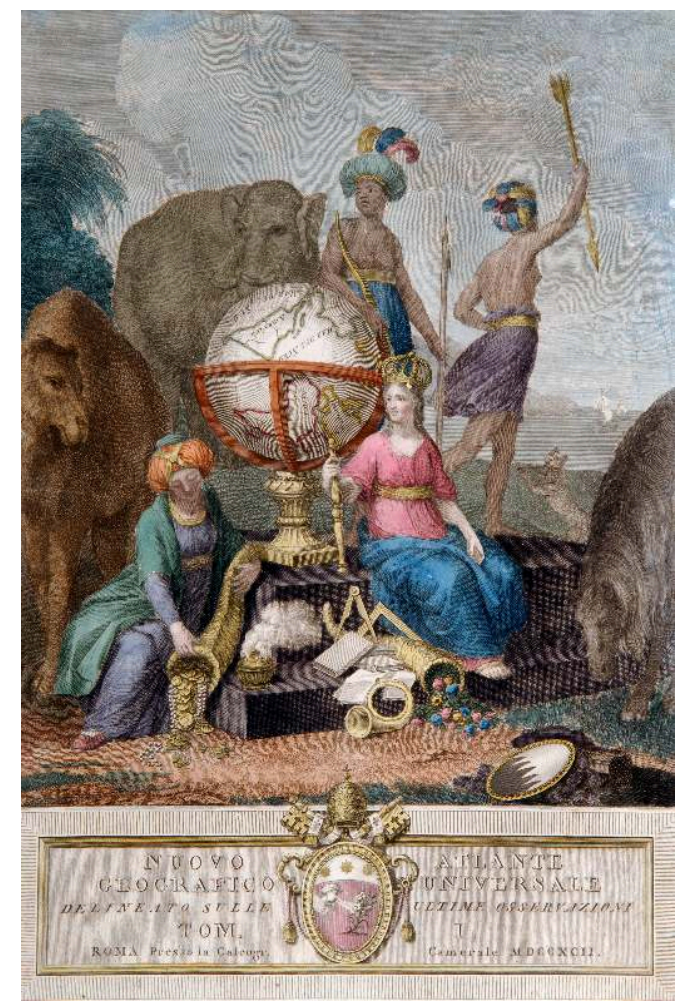


A changed representation of Europe can be seen in the Atlante Linguistico D'Europa a little-known linguistic atlas by Bernardino Biondelli published from Milan in 1841. The engraver is P. Berlotti. The large frontispiece (Figure 9) shows a graceful figure representing Europe, clad in a flowing slit-leg Empire style dress, and standing by a globe placed on a classical plinth. In the background is an inclined tower suggesting the Tower of Babel, and different tomes of a linguistic nature are lying in the foreground. One is labelled "Grimm" and, below, "Rask Vater". These names refer to the brothers Grimm (Jakob and Wilhelm), famed for their "Children's and Household Tales", and to the contemporary Danish philologist Christian Rasmus Rask. To the right, behind a tub of scrolls or papyri, is a small half-hidden bearded figure with a club and hexagonal shield, perhaps one of the dwarfs or gnomes associated with the tales of the Brothers Grimm. Peering over this scene from the right of the globe is a beady-eyed eagle.

Figure 9. Frontispiece to the Atlante Linguistico D'Europa of Bernardino Biondelli, Milan, 1841.

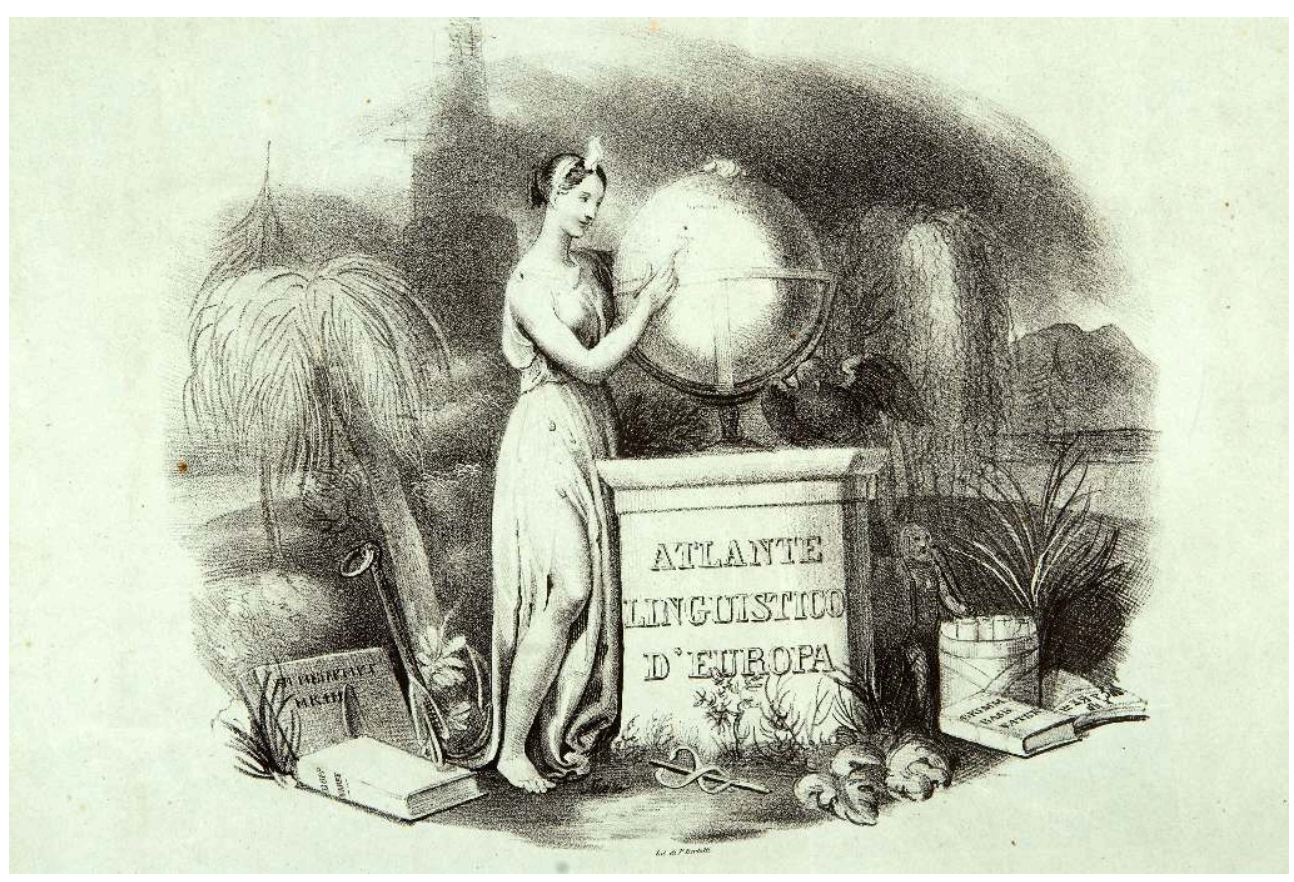

The final image of Europe (Figure 10) comes from a small map dating from the 1880s, part of a set of trade advertising cards. A map of Europe is overprinted with the unspecified address “Au Soulier D'Or, 48-50 rue Esquermoise, Lille”. Below the map the half-kneeling figure of Europe, loosely robed and with a radiant diadem, is flanked by the armorial shields of the ten principal countries of the continent, including Turkey and Russia. The figure of Europe points to the scroll she is holding on which are named her cultural attributes: Art, Science, Industry, Commerce and Progress. In the background can be seen a steam train on a viaduct, a lighthouse, a powered boat, factories and classical buildings, a forge and a printing press and an anchor representing trade. At the foot is the monogram "A C". 
Figure 10. Trade card map of Europe, Lille, c.1880.

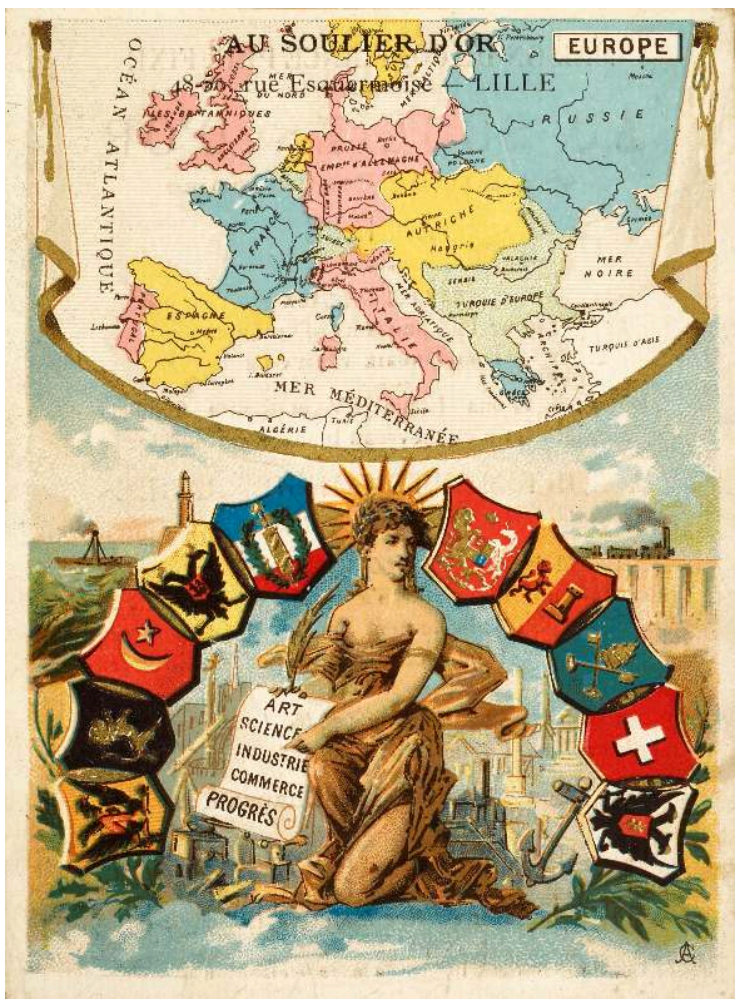

17 Decorative and symbolic titlepages became fewer and fewer by the end of the $19^{\text {th }}$ century and are rarely found thereafter. Three graphic works that treat Europe historically and as an entity, are listed in the references below under "further reading". However, the books themselves omit any emblematic titlepage and carefully sidestep debate about Europe's geographic extent today, its role in the world, its internal coherence and future political structure. On one side it might be argued that there is little point in transposing $21^{\text {st }}$ century concerns about the wider Europe into long-past icons. Alternatively, with a little imagination it should be possible for present-day designers and artists to produce a lively decorative frontispiece or titlepage of contemporary relevance. The fourth book is a recently published work by Rodney Shirley, the author, and is a substantial volume with 274 pages and 180 illustrations (115 in full colour) covering a wide selection of cartographic titlepages and frontispieces with detailed textual discussion.

\section{Further reading}

BRACKE W. et al. (2007), Formatting Europe: Mapping a Continent, Brussels, Bibliothèque royale de Belgique [KBR], illustrated catalogue of ten centuries of maps of Europe. Published in French and Dutch editions.

PLIHÁL K. \& HAPÁK J. (2005), Maps of Europe 1520-2001, Budapest, Helikon Published in Hungarian, German and English editions.

PASTOUREAU M. \& SCHMITT J.-C. (1990), Europe, Mémoire et Emblème, Paris, Editions de l'Epargne. 
SHIRLEY R. (2009), Courtiers and Cannibals, Angels and Amazons: the Art of the Decorative Cartographic Titlepage, published in English by HES \& De Graaf, 3990 G H Houten, The Netherlands.

\section{NOTES}

1. For an elaboration of the meaning of Ortelius' titlepage, see SHIRLEY R. (1998), "The Titlepages to the Theatrum and Parergon", in VAN DEN BROECKE M., VAN DER KROGT P. and MEURER P. (ed.), Abraham Ortelius and the First Atlas, Utrecht, HES, pp. 161-169.

2. Entry Matthais Quad in MEURER P. (1988), Atlantes Colonienses, Bad Neustadt.

3. VAN DER KROGT P. (ed.) (2005), Joan Blaeu's Atlas Maior of 1665, Taschen, pp. 76-78 (enlarged frontispiece ; also texts by Joan Blaeu and Albert Camus).

4. For a full discussion of Merian's engravings see WÜTHRICH I. H. (1966-1993), Das Druckgraphische Werk von Matthaeus Merian, 4 vols, Hamburg, especially volume 3 for collation details of the Theatrum Europaeum.

5. See La Cartografia Italiana, Institut Cartogràfic de Catalunya (1993), pp.191-194 ; also the entry Giovanni Maria Cassini in FRENCH J. (ed.) (1999), Tooley's Dictionary of Mapmakers A-D.

\section{ABSTRACTS}

From the $16^{\text {th }}$ century onwards many map-makers and authors provided decorative titlepages or frontispieces at the beginning of their works. These often displayed allegorical images and symbols reflecting the books' contents, in order to attract potential readers. This contribution looks at some notable examples depicting images of Europe. Similar visual pictures often occur in the cartouches of maps of Europe. One mythological image frequently used was that of the rape of Europa by the god Jupiter disguised as a bull, a fable based on Ovid's Metamorphoses. Other representations show Europe seated on a throne, as a superior ruler of other continents or, later, as the sponsor of the arts and the sciences. In some titlepage engravings of the $17^{\text {th }}$ century she is shown defending the continent from the attacks of the Ottomans from the east. Later $19^{\text {th }}$ century images may depict Europe in a more nationalistic role, flanked by each country's armorial shield.

A partir du XVI ${ }^{\mathrm{e}}$ siècle beaucoup de cartographes et d'auteurs ont produit des pages titres ou des frontispices décoratifs en début de leurs ouvrages. Ceux-ci montraient souvent des images et symboles allégoriques reflétant le contenu du livre dans le but d'attirer des lecteurs potentiels. Cet article examine quelques exemples notables en matière d'images de l'Europe. Les mêmes 
images visuelles se retrouvent souvent dans les cartouches des cartes de l'Europe. Une image mythologique fréquemment utilisée était celle de l'enlèvement d'Europe par le dieu Jupiter déguisé en taureau, une fable basée sur les Métamorphoses d'Ovide. D'autres représentations montrent l'Europe assise sur un trône, tel un dirigeant régnant sur les autres continents, ou, plus tard, comme un promoteur des arts et des sciences. Dans plusieurs gravures du XVII ${ }^{\mathrm{e}}$ siècle elle est aussi représentée en train de défendre le continent des attaques des Ottomans venus de l'Est. D'autres images du XIX ${ }^{\mathrm{e}}$ siècle la montrent parfois dans un rôle plus nationaliste, flanquée des armoiries de chaque pays.

\section{INDEX}

Mots-clés: Europe, enlèvement, Ovide, page-titre, frontispice, cartouche

Keywords: Europe, rape, Ovid, titlepage, frontispiece, cartouche

\section{AUTHOR}

\section{RODNEY SHIRLEY}

The Manor House, Church Street, Buckingham MK18 1 BY, UK, Tel 00-440-1280-81 2158 ,

Rodneyws@dsl.pipex.com 